\title{
Spatial decision support for crop structure adjustment - a case study for selection of potential areas for sorghum (Sorghum bicolor (L.) Moench) production
}

\author{
János JóvÉR, Elza KovÁcs, Péter RICZU, János TAMÁs, Lajos BLASKó
}

Department of Water and Environmental Management, Faculty of Agricultural and Food Sciences and Environmental Management, University of Debrecen,

Debrecen

\begin{abstract}
One option for adaptation to climate change is to grow a wider variety of plant species. Sorghum (Sorghum bicolor (L.) Moench) is known to tolerate unfavourable environmental conditions, so it may be feasible to grow it on areas with extreme conditions to replace other species such as maize. Nowadays, spatial decision supporting systems primarily support the crop production process rather than crop structure adjustment. In this study, potential sorghum production sites in the Great Hungarian Plain were selected based on soil characteristics including genetic soil type, parent material, physical soil type, clay composition, water management, $\mathrm{pH}$, organic matter content, topsoil thickness and fertility, as well as climatic data, particularly precipitation. For all the parameters the aim was to find the extreme values at which sorghum, which is less sensitive than maize, may still give an acceptable yield. By combining map layers of soil characteristics, it could be concluded that although the soil is suitable for sorghum on $40.46 \%$ of the Great Hungarian Plain, maize is generally a better choice economically. On the other hand, the soil conditions on $0.65 \%$ of the land are still suitable for sorghum but unfavourable for maize. As regards the precipitation demand of sorghum, May is the critical period; on 698,968 ha the precipitation required for germination was only recorded once in the period 1991-2010, so these areas cannot be considererd for sorghum. As a consequence, in an alternative crop rotation system sorghum could be competitive with maize, but both the soil and climate conditions and the demands of the crop need to be assessed. The lack of precipitation in critical phenophases significantly decreases the area where maize can survive. Sorghum, however, may produce an acceptable yield, as it is a drought-resistant species.
\end{abstract}

Keywords: soil characteristics, precipitation, arable lands, AGROTOPO, CarpatClim

Postal address: JóvéR JÁNOS, Department of Water and Environmental Management, Faculty of Agricultural and Food Sciences and Environmental Management, University of Debrecen, 4032 Debrecen, Böszörményi u. 138., Hungary.

E-mail: jover@agr.unideb.hu 


\section{Introduction}

Scientific opinions differ regarding the origin of Sorghum. LINNÉ (1753), for example, considered that the species originated from India, while according to VAVILOV (1949) the gene centre of this species is in Africa. However, both regions have similar climatic characteristics, forming the basis of the high heat unit demand and good drought tolerance of sorghum. In a comparative analysis, ELAGIN (1957) found that sorghum had better tolerance of the unfavourable impacts of drought than other crops such as maize. The potential of this species was first investigated in Hungary in 1954, when SURÁNYI (1954) experimented with various cultivation technologies, while BAJAI (1960) carried out field experiments to test the drought resistance of different hybrids.

The annual water demand of sorghum is $500-580 \mathrm{~mm}$, with a transpiration coefficient of $150-250 \mathrm{l} \mathrm{kg}^{-1}$, so sorghum requires less water to produce a unit of dry matter than maize, for which this value is about $350 \mathrm{l} \mathrm{kg}^{-1}$ (MUNOR - RACHIE, 1956; Moldenhauer - KeAting, 1958; Pepó - SÁrVÁRI, 2011). So one alternative for the adaptation to drought is to include sorghum in the crop rotation (TUINSTRA et al., 1997; LUX et al., 2002). This is an important issue in Hungary, where maize is the dominant crop, while the size of the irrigated area is much smaller than required even in the short term (JUHÁsZ et al., 2013).

On the other hand, even sorghum is sensitive to water deficit in critical phenophases (germination, early stages of rooting), which may cause yield losses. As these sensitive periods occur 15-18 days after sowing, this also determines the optimal time of sowing. Thus, TóTH (1962) and JózSA (1964) suggest sowing sorghum at the end of April, or at the latest in early of May, where irrigation facilities are available.

Most major soil types in Hungary are suitable for sorghum growing, except heavy loam, and cold or extremely acidic/saline soils (SURÁNYI, 1954; BAJAI, 1957). ANTAL et al. (1966) and GYÖKÉR (1977) proved that sorghum production could be successful even on sandy soils.

Under continental climatic conditions, sorghum production could be a viable option on non-irrigated, drought-affected areas, and also on fields with unfavourable water management characteristics or a thick crust (BÁRDOSSY 1964). However, sorghum production will only be profitable if a satisfactory technology is applied (LADDHA-TOTAWAT, 1997; TSUCHIHASHI-GOTO, 2004).

Today, the problem is not the lack of scientific knowledge on ways of responding to climate change, such as the production of drought-tolerant crops, but the transfer of this knowledge into farm practice. There is a wide range of sitespecific applications using agricultural informatics tools, such as decisionsupporting systems to enhance, for instance, the efficiency of plant production and to mitigate the risks caused by incorrect adaptation to current environmental conditions (Rosa et al., 2003; MeYer - Grabaum, 2008; Mendas - Delali, 2012). 
In this paper, the aim is to describe the application of a set of GIS tools in the form of a case study, so as to reflect their potential role in the selection of arable lands for sorghum production on the basis of soil and climatic parameters.

\section{Materials and methods}

The boundaries of the potential sorghum production zones were determined using spatial databases, focusing on the Great Hungarian Plain. First, in 2006, the Corine Land Cover (CLC) database from the Copernicus Land Monitoring Service was analysed for land use, with data in a raster format with a resolution of $100 \times 100 \mathrm{~m}$. Arable land without irrigation was classified with Idrisi Taiga software.

Table 1

Codes of soils found to be suitable for both maize and sorghum or only for sorghum according to various selection criteria; based on the AGROTOPO (1994) supplement

\begin{tabular}{|l|l|l|}
\hline \multicolumn{1}{|c|}{ Soil properties } & \multicolumn{1}{|c|}{$\begin{array}{c}\text { Land suitable for maize } \\
\text { and sorghum }\end{array}$} & \multicolumn{1}{c|}{$\begin{array}{c}\text { Land only suitable for } \\
\text { sorghum }\end{array}$} \\
\hline Genetic soil type & $03 ; 07 ; 09 ; 11 ; 12 ; 13 ; 14$ & $\begin{array}{c}08 ; 10 ; 15 ; 16 ; 17 ; 18 ; 23 ; \\
24 ; 25 ; 26\end{array}$ \\
\hline Mother rock & $1 ; 2 ; 3 ; 4 ; 5 ; 6 ; 7 ; 8 ; 9$ & $1 ; 2 ; 3 ; 4 ; 5 ; 6 ; 7 ; 8 ; 9$ \\
\hline Physical soil type & $1 ; 2 ; 3 ; 4 ; 5$ & $1 ; 2 ; 3 ; 4 ; 5$ \\
\hline Clay mineral composition & $0 ; 1 ; 2 ; 3 ; 4 ; 5 ; 6 ; 7 ; 8 ; 9$ & $0 ; 1 ; 2 ; 3 ; 4 ; 5 ; 6 ; 7 ; 8 ; 9$ \\
\hline $\begin{array}{l}\text { Soil water management } \\
\text { characteristics }\end{array}$ & $1 ; 2 ; 3 ; 4 ; 5 ; 6 ; 8$ & $1 ; 2 ; 3 ; 4 ; 5 ; 6 ; 8$ \\
\hline Acidity & 4 & $2 ; 3$ \\
\hline Organic matter content & $1 ; 2 ; 3 ; 4 ; 5 ; 6$ & $1 ; 2 ; 3 ; 4 ; 5 ; 6$ \\
\hline Thickness of upper layer & 5 & $3 ; 4$ \\
\hline Soil fertility & $0 ; 1 ; 2 ; 3 ; 4 ; 5 ; 6 ; 7 ; 8 ; 9$ & $0 ; 1 ; 2 ; 3 ; 4 ; 5 ; 6 ; 7 ; 8 ; 9$ \\
\hline
\end{tabular}

Secondly, land suitable for both crops or only for sorghum was identified using the AGROTOPO (1994) soil database with data in a vector format and on the basis of properties such as genetic soil type, mother rock, physical soil type, clay mineral composition, soil water management characteristics, acidity, organic matter content, thickness of upper layer and soil fertility. Certain vector parameters from AGROTOPO (1994) were used as boundary areas to split the CLC database. Map layers for further assessment were created by overlapping the different layers. Table 1 details the selection criteria for the visualization of areas suitable only for sorghum or for both crops.

For climatic analysis, i.e. risk assessment for water shortage in relation to the water demands of the selected crop species, the CarpatClim database for the period 1991-2010 was used with data in a raster format and a resolution of $0.1^{\circ *} 0.1^{\circ}$. For periods when the water supply is critical for sorghum and maize, cumulated precipitation ranges (in $\mathrm{mm} \mathrm{ha}^{-1}$ ) were categorized and plotted. In May, the most 
sensitive period for sorghum, the critical level was represented by $0-10 \mathrm{~mm}$ rainfall. In the case of maize, there are two critical periods, in July and August. Considering the fact that the average precipitation in July and August is about $60 \mathrm{~mm}$, three precipitation categories were set up $(0-20 \mathrm{~mm}, 20-40 \mathrm{~mm}, 40-60 \mathrm{~mm})$. On areas with a precipitation sum of $20-40 \mathrm{~mm}$ the water shortage was considered to be moderate, while $0-20 \mathrm{~mm}$ was critical. Based on the frequency of moderate and critical water shortages, risk assessment was done by calculating the probability (as a percentage) of this level of water shortage.

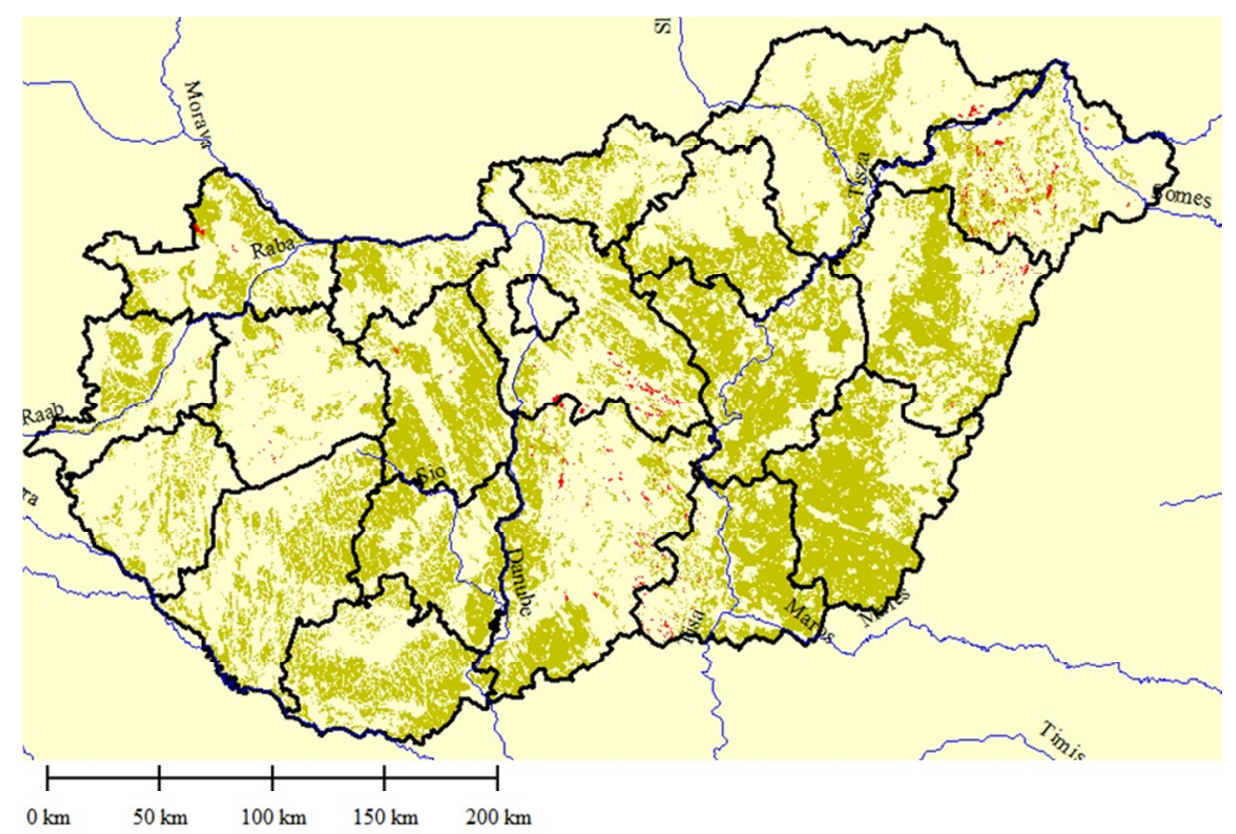

Suitable for maize and sorghum

Suitable only for sorghum

Figure 1

Land in Hungary suitable for both maize and sorghum or only for sorghum

\section{Results and discussion}

The Great Hungarian Plain is the area of Hungary that has the most arable land suitable for crop production. The irrigated areas of the region were ignored in the analysis.

Considering the soil characteristics, an area of 3.1 million ha in Hungary was found to be suitable for both sorghum and maize production, which is $65 \%$ of the country's total area. On the other hand, it was concluded that on 36,500 ha the soil conditions were unfavourable for maize, so it would be preferable to grow sorghum in these areas (Figure 1). 


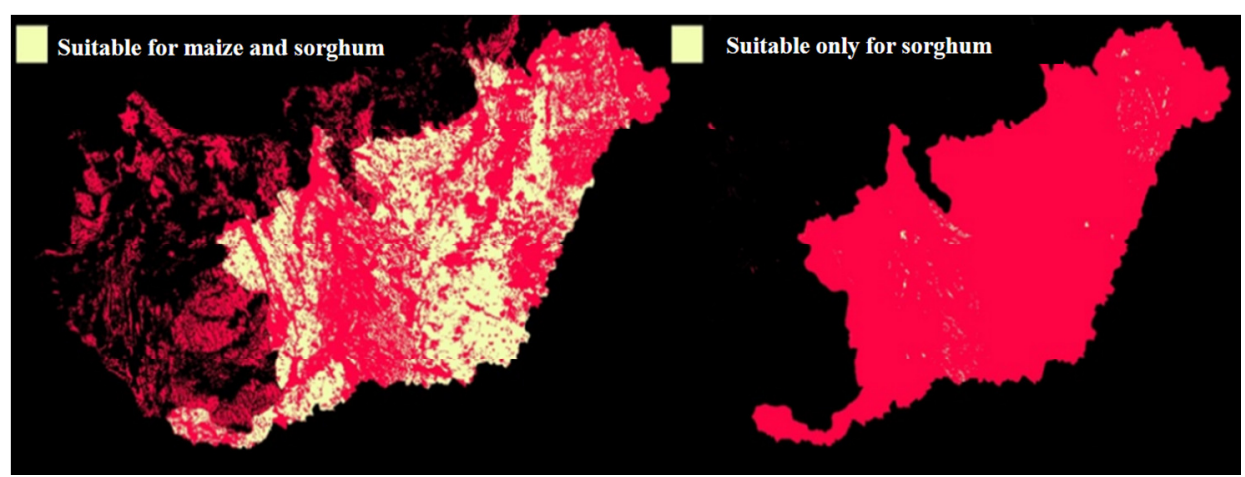

Figure 2

Land on the Great Hungarian Plain suitable for both maize and sorghum or only for sorghum

About 2.1 million ha of the 5.1 million ha making up the Great Hungarian Plain is suitable for both sorghum and maize, while a further 33,100 ha is only suitable for sorghum, so this is the land where it would be advisable to produce sorghum (Figure 2).

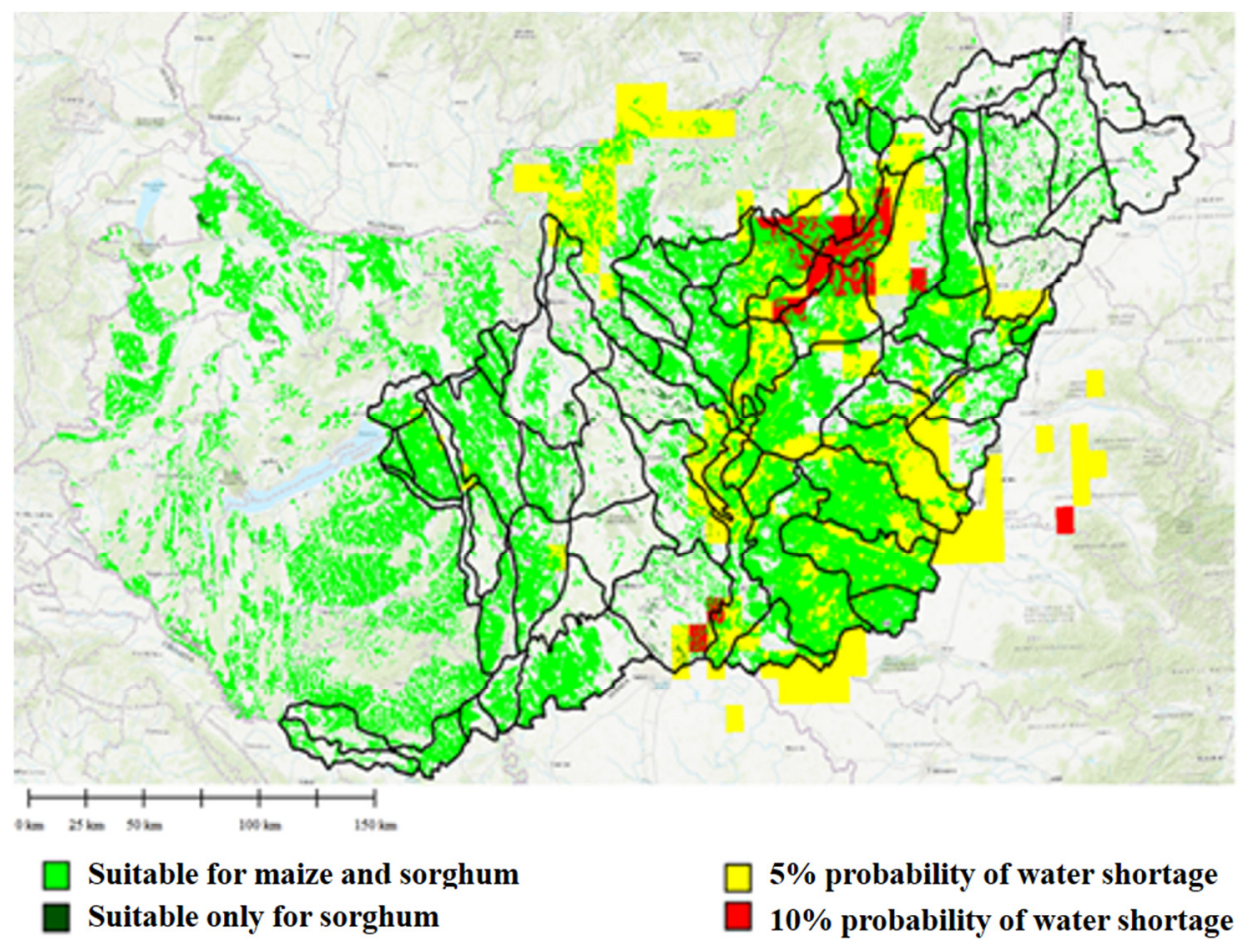

Figure 3

Probability of rainfall deficit in the early development stages of sorghum on land suitable for both maize and sorghum or only for sorghum 
During the period between 1991 and 2010, precipitation of less than $10 \mathrm{~mm}$ was recorded once on 700,000 ha area, and twice on 71,000 ha at the beginning of May. There is thus a $5 \%$ probability of rainfall deficit on $34 \%$ of the land suitable for both maize and sorghum and a $10 \%$ probability on $3.5 \%$. In the case of the areas where sorghum should be grown by preference, there is a $5 \%$ probability of rainfall deficit in this period on 2,300 ha and a 10\% probability on 400 ha (Figure 3).

Sorghum and maize are fairly similar as regards morphology and phenology, but exhibit significant differences in their adaptation to environmental conditions.

For instance, a sufficient water supply in the generative phases in July and August is crucial for maize production under Hungarian climatic conditions, and decisively affects the final yield compared to the genetic potential of the species. Thus, on areas where water shortage is likely during these periods, the production of sorghum instead of maize can be expected to be more efficient. Based on the precipitation pattern in the decades considered in the present study, precipitation was below $20 \mathrm{~mm}$ once on 631,000 ha of the arable land suitable for sorghum, representing a 5\% probability of a deficit occurring, and below $20 \mathrm{~mm}$ on four occasions on 800 ha of land, a probability of $20 \%$.

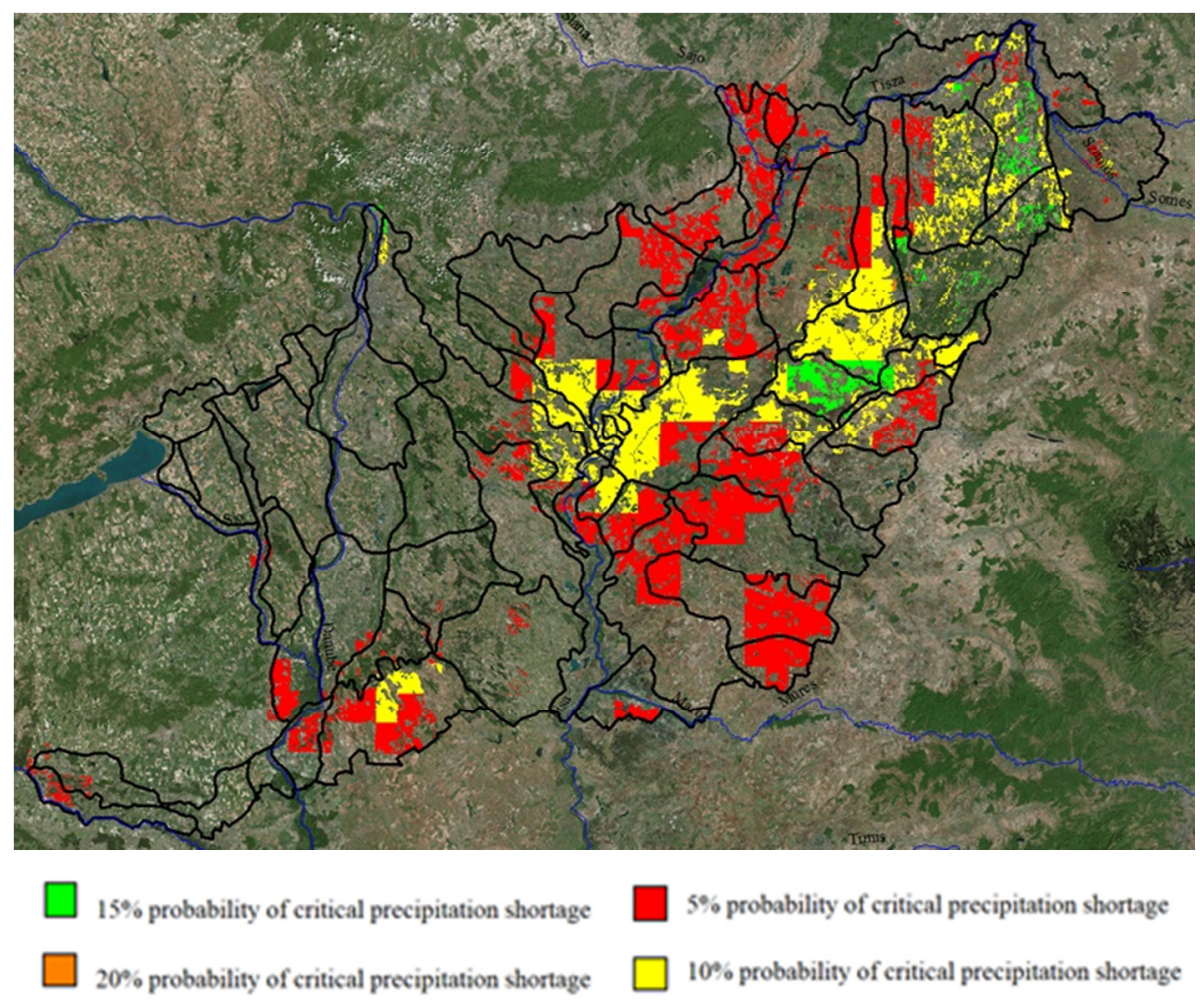

Figure 4

Probability of precipitation less than $20 \mathrm{~mm}$ in July 
Table 2

Relative frequency of precipitation categories in July on land suitable for sorghum production (ha) between 1991 and 2010

\begin{tabular}{|c|r|r|r|}
\hline Relative frequency & $\begin{array}{c}0-20 \mathrm{~mm} \\
\text { precipitation } \\
\text { category }\end{array}$ & $\begin{array}{c}\text { 20-40 mm } \\
\text { precipitation } \\
\text { category }\end{array}$ & $\begin{array}{c}40-60 \mathrm{~mm} \\
\text { precipitation } \\
\text { category }\end{array}$ \\
\hline 1 & 630987 & 12986 & 89734 \\
\hline 2 & 352623 & 142741 & 233048 \\
\hline 3 & 46187 & 396960 & 385889 \\
\hline 4 & 798 & 544139 & 387404 \\
\hline 5 & - & 389268 & 403532 \\
\hline 6 & - & 308162 & 299270 \\
\hline 7 & - & 122205 & 202140 \\
\hline 8 & - & 94061 & 20209 \\
\hline 9 & - & 13389 & - \\
\hline
\end{tabular}

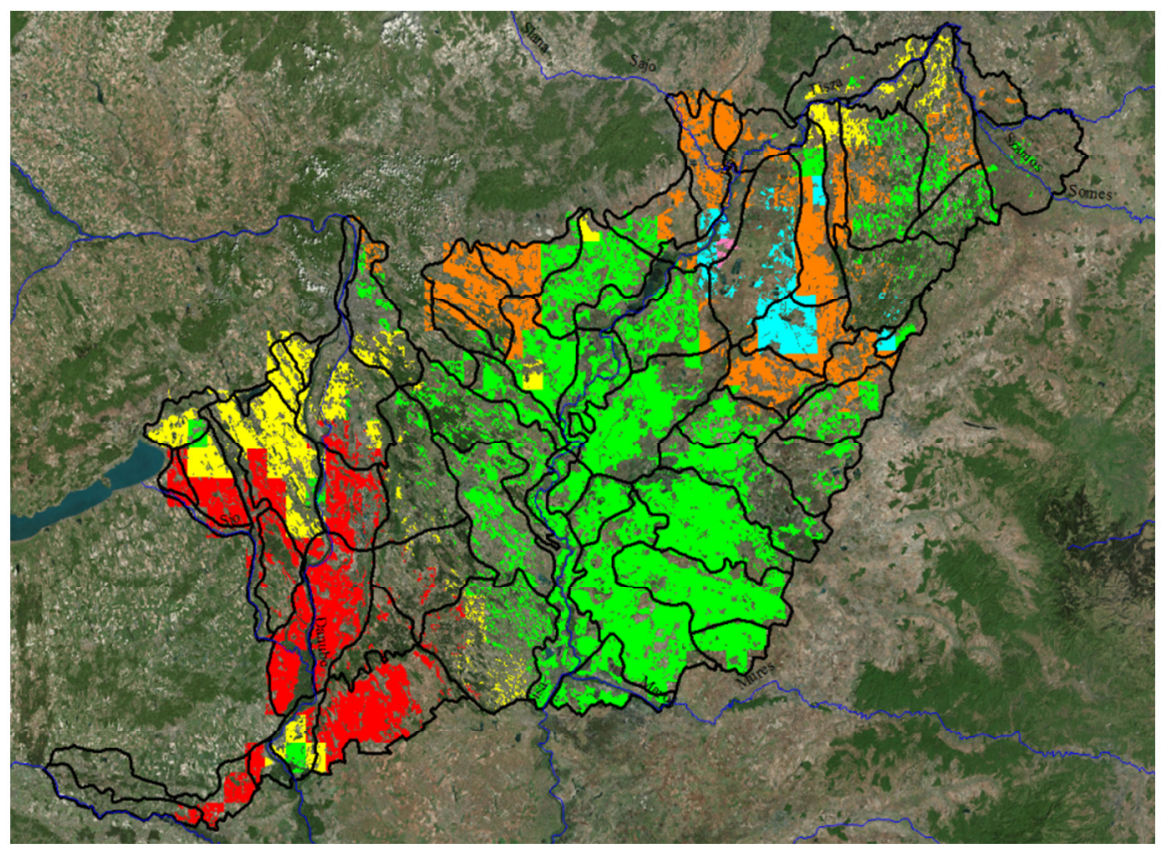

$5 \%$ probability of critical precipitation shortage

$20 \%$ probability of critical precipitation shortage

$10 \%$ probability of critical precipitation shortage

$25 \%$ probability of critical precipitation shortage

$15 \%$ probability of critical precipitation shortage

$30 \%$ probability of critical precipitation shortage

Figure 5

Probability of maximum precipitation of less than $20 \mathrm{~mm}$ in August 
Analysing the precipitation sum in July, it can be concluded that besides the high frequency of extreme rainfall deficit, moderate water shortage with precipitation between $20 \mathrm{~mm}$ and $40 \mathrm{~mm}$ is also very frequent (Table 2). Altogether, a significant part of the land suitable for sorghum suffers from moderate precipitation deficit, the probability of which is $45 \%$ on 13,389 ha.

Considering the data for August, 3,300 hectares were classified as having a 30\% probability of extreme rainfall deficiency. This was particularly true of the northern part of the Great Hungarian Plain, while the risk was lower in the western part (Figure 5).

Over the two decades, the distribution of precipitation in August showed significant variation. However, a large part of the Great Hungarian Plain can be expected to have very low precipitation in August, which draws attention to the benefit of producing sorghum as a drought-tolerant crop (Table 3).

Table 3

Relative frequency of precipitation categories in August on land suitable for sorghum production (ha) between 1991 and 2010

\begin{tabular}{|c|r|r|r|}
\hline Relative frequency & $\begin{array}{c}\text { 0-20 mm precipitation } \\
\text { category }\end{array}$ & $\begin{array}{c}\text { 20-40 mm } \\
\text { precipitation category }\end{array}$ & $\begin{array}{c}40-60 \mathrm{~mm} \\
\text { precipitation category }\end{array}$ \\
\hline 1 & 320081 & 4810 & 26950 \\
\hline 2 & 216579 & 55122 & 189422 \\
\hline 3 & 1049735 & 320522 & 382046 \\
\hline 4 & 327759 & 611903 & 485622 \\
\hline 5 & 74679 & 589608 & 397533 \\
\hline 6 & 3268 & 383567 & 274865 \\
\hline 7 & - & 50896 & 146739 \\
\hline 8 & - & 5421 & 33255 \\
\hline 9 & - & 2107 & 2060 \\
\hline 10 & - & - & 319 \\
\hline
\end{tabular}

When rainfall shortages in both July and August, during the generative development phase of maize, were considered, $97 \%$ of the land suitable for both maize and sorghum was found to be affected by extreme rainfall deficiency at least once during the two decades investigated (Figure 6). On 1,082 hectares of land, there was a $40 \%$ probability of water shortage, which clearly requires the application of irrigation even for the cultivation of drought-tolerant crops. 


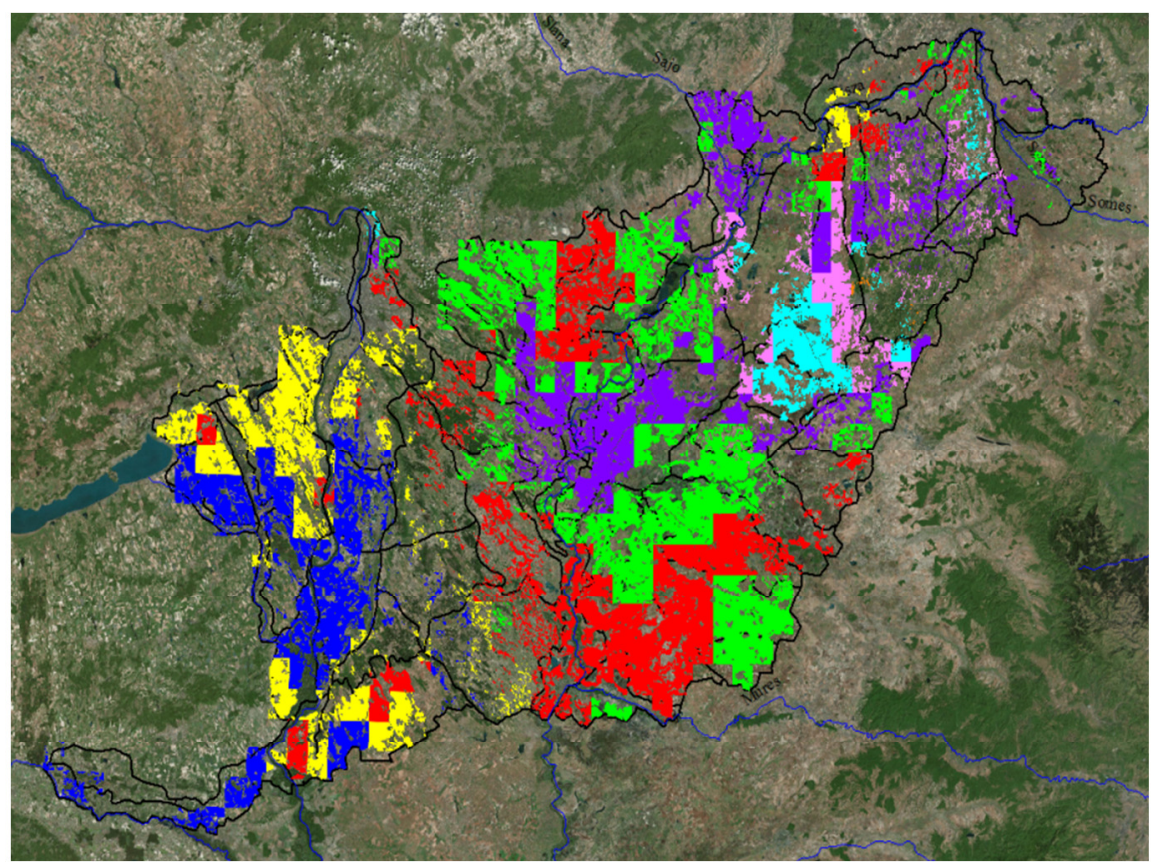

$5 \%$ probability of critical precipitation shortage $10 \%$ probability of critical precipitation shortage $15 \%$ probability of critical precipitation shortage $20 \%$ probability of critical precipitation shortage

$\square 25 \%$ probability of critical precipitation shortage $30 \%$ probability of critical precipitation shortage $35 \%$ probability of critical precipitation shortage $40 \%$ probability of critical precipitation shortage

Figure 6

Spatial visualization of the land affected by water deficit in July and August

\section{Conclusions}

Production planning is usually based on an iteration process. Decision-making can only be efficient if environmental aspects are considered, which requires relevant datasets for the decisive factors. Nowadays a wide range of databases are available in several formats for use in decision support systems.

Cartography, as a special field of visualization, generally presents data in a specific graphical format. Visualization is a convenient and effective way of presenting information, while the analysis of numbers and tables is generally difficult and less effective. Map layers provide data in a comprehensible format, enabling the user to visualize spatial relationships.

Spatial decision support for crop structure adjustment is an effective method to enhance the efficiency of crop production. By determining the criteria for crop production based on environmental conditions, land suitable for various plant species can be visualized as map layers, the use of which makes it possible to 
combine various criteria in order to build up a complex supporting system for sitespecific crop production.

\section{Acknowledgements}

This research was funded by the Arid Land Research Center, University of Debrecen, Hungary.

\section{References}

AGROTOPO (1994). VÁrallyay G., SZABó J., PÁSZTOR L. Agrotopographical database, MTA ATK TAKI, Budapest.

https://maps.rissac.hu:3344/webappbuilder/apps/2/

Antal, J., Egerszegi, S., PenYigey, D., 1966. Crop production on sand. Mezőgazdasági Kiadó. Budapest. 202-206. (In Hungarian)

BAJAI, J., 1957. Improving the production of forage sorghum up to 1975 , with special regard to the supply of fodder in the dry areas of the country and the use for spirits and cellulose purposes. Martonvásár. (In Hungarian)

BAJAI, J., 1960. Importance of sorghums grown for stock food in the forage production of Hungary. Acta Agronomica. 10. 345-408.

BÁRDOSSY, A., 1964. Data for fertilizing grain sorghum. Mosonmagyaróvári Agrártudományi Főiskola Közleményei. 7. 87-90. (In Hungarian)

ElaGiN, I. N., 1957. Basic questions of sorghum production. Vest. S. H. Nauki. 4. 55-60. (In Russian)

GYÖKÉR, A., 1977. The application of sorghum. Magyar Mezőgazdaság. XXXI. 41.sz. 7-8. (In Hungarian)

JózSA, L., 1964. The production of grain sorghum. Hajdú-Bihar megye Tanács és TIT kiadványa. Debrecen. (In Hungarian)

JuHÁSZ, C., RÁTONYI, T., HARSÁNYI, E., NAGY, J., SZÉLES, A., 2013. Situation and development possibilities of irrigation in Hungary. Infrastruktura I Ekologia Terenów Wiejskich / Infrastructure and Ecology of Rural Areas 3. 45-54.

LadDHA, K. C., Totawat, K. I., 1997. Effect of deep tillage under rainfed agriculture on production of (Sorghum bicolor L. Moench) intercropped with green gram (Vigna radiate) in western India. Soil \& Tillage Research. 43. 241250.

LINNÉ, C.V., 1753. Species Plantarum. Stockholm. Holmiae. 2. 1047-1048.

LuX, A., LuXovÁ, M., HATTORI, T., InANAGA, S., 2002. Silicification in sorghum (Sorghum bicolor) cultivars with different drought tolerance. Physiologia Plantarum. 115. 87-92.

Mendas, A., Delali, A., 2012. Integration of multicriteria decision analysis on GIS to develop land suitability for agriculture: Application to durum wheat cultivation in the region of Mleta in Algeria. Computers and Electronics in Agriculture. 83. 117-126. 
Meyer, B. G., Grabaum, R., 2008. MULBO: Model framework for multicriteria landscape assessment and optimisation. A support system for spatial land use decisions. Landscape Research. 33. 155-179.

Moldenhauer, W. C., Keating F. E., 1958. Relationship between climatic factors and yields of cotton, milo and cafir on sandy soils in the southern high plains. Production Research Report, US Department of Agriculture. Texas. 13.

MunOR, J. M., RACHIE, K. O., 1956. The influence of elevation and climate on maturity and yield of some grain sorghum varieties. Agronomical Abstracts. 49. 49.

PEPÓ, P., SÁRVÁRI M., 2011. Production of cereal crops. University of Debrecen, Debrecen. (In Hungarian)

Rosa D. D., Mayol, F., Diaz-Preira, E., Fernandez, M., Rosa, D. D., JR., 2003. A land evaluation decision support system (MicroLEIS DDS) for agricultural soil protection: With special reference to the Mediterranean region. Environmental Modelling \& Software. 19. 929-942.

SURÁNYI, J., 1954. About Forage sorghum. Mezőgazda Kiadó, Budapest. (In Hungarian)

TótH, J., 1962. When and how to sow sorghum? Magyar Mezőgazdaság 7. 7. (In Hungarian)

TSUCHIHASHI N., GoTO, Y., 2004. Cultivation of sweet sorghum (Sorghum bicolor L. Moench) and determination of its harvest time to make use as raw material for fermentation, practiced during rainy season in dry land of Indonesia. Plant Production Science. 7. 442-448.

Tuinstra, M. R., Grote E. M., Goldsbrough, P. B., Ejeta, G., 1997. Genetic analysis of post-flowering drought tolerance and components of grain development in Sorghum bicolor (L.) Moench. Molecular Breeding. 3. 439-448.

VAVILOV, N. I., 1949. The origin, variation, immunity and breeding of cultivated plants. Chronica Botanica. 14. 364. 